\title{
The Behavior of Stage House Inhabitant Towards the Provision of Safe Drainage to the Environment in Soppeng District
}

\author{
Rahmansah Rahmansah, Mithen Lullulangi \\ Civil Engineering Education Department, Universitas Negeri Makassar, Makassar, Indonesia
}

Email address:

rahmansah@unm.ac.id (R. Rahmansah), mithen@unm.ac.id (M. Lullulangi)

\section{To cite this article:}

Rahmansah Rahmansah, Mithen Lullulangi. The Behavior of Stage House Inhabitant Towards the Provision of Safe Drainage to the Environment in Soppeng District. International Journal of Architecture, Arts and Applications. Vol. 5, No. 1, 2019, pp. 29-36. doi: $10.11648 /$ j.ijaaa.20190501.14

Received: March 19, 2019; Accepted: May 16, 2019; Published: June 13, 2019

\begin{abstract}
The aim of this research was to study the behavior of stage house inhabitants towards the provision of safe drainage to the environment in Soppeng District and also to understand the influence of some environmental factors on them, both individually and collectively. For the purpose, Marioriwawo, Lilirilau, and Marioriawa Sub-districts were selected by random respondents while 50 family heads $(\mathrm{FH})$ were selected in each sub-district using purposive respondents method. Therefore, 150 family heads constituted the respondents size. Behavior towards the provision of safe drainage to the environment was the dependent variable while the independent include environmental knowledge, conservation, as well as attitudes and motivation to maintain the environment. Descriptive and inferential statistical were used in analyzing the results through simple and multiple regressions. The results of the study showed that the behavior of the stage house inhabitants towards the provision of safe drainage to the environment in Soppeng District is moderate and needs improvement. It also found that the environmental factors stated above are moderate and, individually and collectively influences the behavior of the inhabitants.
\end{abstract}

Keywords: Behavior, Attitude, Drainage, Eenvironment, Stagehouse

\section{Introduction}

Law No. 32 is concerned with the protection and management of environment [1] by ensuring that there are systematic and integrated efforts toward its preservation through proper planning, utilization, control, maintenance, supervision, and law enforcement. Emil Salim, points out that development is a continuous process with an impact on both the population and environment, therefore, it is necessary to harmonize these two in order to create conducive conditions for the sustainable process [2]

Hunggerfort, H. R, \& Volk, T. L, state that responsible environmental behavior is determined by many factors such as personality, knowledge of issues and other situational ones [3]. Similarly, Martin and Pear in Tukiyat reveal that behavior is a result of the continuous actions of an individual based on situations [4].

Furthermore, Adnil and Notoatmodjo basically argue that behavior is a human activity that can be observed, both directly or indirectly, through their actions, thoughts, and feelings [5]. Rambo, points out that human behavior is mostly determined by their natural habitat [6]. This theory is popularly known as Environmental Determinism and it considers that all aspects of culture and human behavior are caused directly by environmental influences. Sarwono, states that human nature has the ability to learn from experience and that this is the reason their behavior changes with the environment [7].

Notoatmodjo and Suriasumantri, reveal that knowledge comes as a result of 'knowing' through the sensing of a particular object [8]. Furthermore, they observed that it has to do with special and general memories of various methods and processes or patterns, structures or conditions. It can also be classified into the knowledge of specific matters including terms and facts; dealing with specific problems such as habits, attitudes, classifications, and categories; and universal 
rules including principles, theories, and structures.

However, Bloom and Kratwohl in Rusman as quoted by Rahmat, classify knowledge to be a cognitive domain with six thinking aspects which include knowledge, comprehension, application, analysis, synthesis, and evaluation [9].

According to Achmadi, an environment is the unity of space where all objects, power, circumstances, and living things affect their continuity of life and welfare [10]. Adnani, divides the environment into 3 parts and these include biological in the form of food and disease source; physical which has to do with soil, air, climate, water, and other basic human needs, and social through the economic system, traditional community organizations and various human services [11]. According to Frytxell \& Lo environmental knowledge in the form of knowledge that contains reality, concepts, and interactions with the natural environment and the whole ecosystem [12].

In Law No. 32 concerning protection and management of the environment, Chapter 1 article 1 point 18 states that conservation of natural resources has to do with its management to ensure its efficient utilization and sustainability while maintaining and improving the quality of its values and diversity [1]. Tisdale and Arsyad also reveal that it involves the use of the biosphere to produce greater profits for the current generation while maintaining its potential for future generations [13].

Chave and Scornd and Backman cited by Azwar define attitudes to be certain consistencies in terms of feelings, thoughts and predisposing one's actions towards an environmental object [14]. Linggasari shows that attitudes consist of various levels: accepting, responding, appreciating, and taking responsibility for everything that has been chosen [15]. Holhan in Ojedokun explains that environmental attitudes are people's feelings to accept or reject some characteristics or issues related to the physical environment [16].

At the same time, Azwar reveals that attitudes consist of 3 components including the cognitive which involves a person's beliefs about what is valid and true; affective which has to do with one's emotional problems; and conative which shows a person's tendency to behave towards an object [14].

Soewarno defines motivation to be the urge of an individual or human to carry out an action for the purpose of achieving a goal [17]. Djamarah and Taufik show that it can be divided into intrinsic which involves a drive from within and extrinsic which can be seen as active motives because of the presence of stimulants from the outside [18].

Therefore, it is necessary to conduct a research on the factors that influence the behavior of stage house inhabitants in providing safe drainage to the environment. This involved examining the behavior of inhabitants towards the provision of safe drainage, understanding the impact of environmental factors such as environmental knowledge, environmental conservation knowledge, motivation and attitudes towards the environment as well as their individual and joint influence on the stage house inhabitants of Soppeng District.

\section{Research Methods}

i. The study made use of a correlational method. Three sample districts including Marioriwawo, Lilirilau, and Marioriawa were selected using a random sampling method and the population consisted of low to middleincome family heads (FH). Purposive sampling was used to select 50 of them from each sub-district and this made the total respondent for the research to be 150 FHs.

ii. The dependent variable (Y) was community behavior in providing healthy housing drainage while the independent variables were environmental knowledge $\left(\mathrm{X}^{1}\right)$; environmental conservation knowledge $\left(\mathrm{X}^{2}\right)$; attitude towards the environment $\left(\mathrm{X}^{3}\right)$; and motivation to maintain the environment $\left(\mathrm{X}^{4}\right)$.

iii. Descriptive statistical analysis was used to determine the average, maximum, minimum, frequency distribution, standard deviation, and histogram of each variable while inferential statistical analysis was used to determine the influence of independent variables on the dependent variable. The analysis models used were simple and multiple regressions.

\section{Results}

\subsection{Behavior of the Community (Y)}

To find out the description of the behavior of the community providing drainage on a stilt house that is safe for the environment, out of the 8 observations observed, the following are the results of descriptive statistical analysis (frequency distribution) shown in table 1.

Table 1. Frequency distribution of community behavior in providing drainage to stilt houses that are safe for the environment.

\begin{tabular}{llllll}
\hline No & Description Score & & Frequency & Percentage (\%) & Cumulative Percentage (\%) \\
\hline 1 & Very low & $8-14$ & 0 & 0 & 0 \\
2 & Low & $15-21$ & 33 & 22,00 & 22,00 \\
3 & Medium & $22-28$ & 84 & 56,00 \\
4 & Height & $29-34$ & 33 & 22,00 & 78,00 \\
5 & Very hight & $35-40$ & 0 & 0 & 100 \\
Amount of & & & 150 & 100 \\
\hline
\end{tabular}

Based on statistical analysis, Table 1 can be understood that there are no respondents who have very low and very high behavior. As many as $22.00 \%$ who have low behavior, as many as $56.00 \%$ who have moderate behavior and as many as $22.00 \%$ who have high behaviors provide drainage on stage houses that are safe for the environment. To find out the category 
of behavior of the community providing drainage on a stilt house that is safe for the environment in Soppeng District, the following are the results of descriptive statistical analysis in Table 2.

Table 2. Results of descriptive statistical analysis (Y).

\begin{tabular}{llllll}
\hline Descriptive Statistics & & & & \\
\hline & N & Minimum & Maximum & Mean & Std. Deviation \\
\hline Y & 150 & 17,00 & 33,00 & 25,1200 & 4,75567 \\
Valid N (listwise) & 150 & & & & \\
\hline
\end{tabular}

The data obtained from 8 questions showed that the variable has an average value of 25.12 with the maximum at 33 and minimum at 17. When associated with frequency distribution, it means that it is in the medium category. Therefore, it can be concluded that the behavior of the community to provide safe drainage in a stage house to the environment in Soppeng Regency is moderate and calls for improvement.

\subsection{Environmental Knowledge $\left(X^{1}\right)$}

Table 3. Results of descriptive statistical analysis $\left(X^{1}\right)$.

\begin{tabular}{lllll}
\hline Descriptive Statistics & & & & \\
\hline & N & Minimum & Maximum & Mean \\
\hline$X^{1}$ & 150 & 3,00 & 8,00 & 5,7600 \\
Valid N (listwise) & 150 & & & 1,44092 \\
\hline
\end{tabular}

The data obtained from 10 questions showed that the variable has an average value of 5.76 with the maximum at 8 and minimum at 3 . If it is associated with the frequency distribution, the value is in the medium category. Therefore, it can be concluded that environmental knowledge is moderate and calls for improvement.

\subsection{Environmental Conservation Knowledge $\left(X^{2}\right)$}

Table 4. Results of descriptive statistical analysis $\left(X^{2}\right)$.

\begin{tabular}{lllll}
\hline Descriptive Statistics & & & & \\
\hline & N & Minimum & Maximum & Mean \\
\hline $\mathrm{X}^{2}$ & 150 & 3,00 & 8,00 & 5,7400 \\
Valid N (listwise) & 150 & & & 1,47202 \\
\hline
\end{tabular}

The data obtained from 10 questions showed that the variable has an average value of 5.74 with the maximum at 8 and minimum at 3. The value is on the medium category on the frequency distribution. Therefore, it can be concluded that the knowledge of community environmental conservation in the stage houses of Soppeng Regency is moderate and needs to be improved.

\subsection{Attitudes Towards the Environment $\left(X^{3}\right)$}

Table 5. Results of descriptive statistical analysis $\left(X^{3}\right)$.

\begin{tabular}{lllll}
\hline Descriptive Statistics & & & & \\
\hline & N & Minimum & Maximum & Mean \\
\hline $\mathrm{X}^{3}$ & 150 & 20,00 & 36,00 & 31,2000 \\
Valid N (listwise) & 150 & & & 5,09243 \\
\hline
\end{tabular}

The data gotten from the analysis of the 10 items of statements for this variable revealed that the average value was 31.20 at a maximum of 36 and a minimum of 20. If this is associated with frequency distribution, it is in the medium category. Therefore, it can be concluded that the attitude of stage house inhabitants towards the Soppeng Regency environment is in the positive tendency transition category. Therefore, it needs to be improved.

\subsection{Motivation to Maintain the Environment $\left(X^{4}\right)$}

Table 6. Results of descriptive statistical analysis $\left(X^{4}\right)$ Descriptive Statistics.

\begin{tabular}{|c|c|c|c|c|c|}
\hline & $\mathbf{N}$ & Minimum & Maximum & Mean & Std. Deviation \\
\hline $\mathrm{X}^{4}$ & 150 & 20,00 & 38,00 & 31,5200 & 5,17573 \\
\hline Valid N (listwise) & 150 & & & & \\
\hline
\end{tabular}

The data gotten from the analysis of the 10 items of statements for this variable showed that the average value was 31.52 at a maximum of 38 and a minimum of 20 . If this is associated with frequency distribution, it is also in the medium category. Therefore, it can be concluded that the motivation to maintain the environment is moderate and 
needs to be improved.

\subsection{Effect of $X^{1}$ on $Y$}

To find out the effect of $\mathrm{X}^{1}$ on $\mathrm{Y}$, the following are the results of a simple regression analysis (Anova Table) in Table 7.

Table 7. Effect of $X^{l}$ on $Y$.

\begin{tabular}{|c|c|c|c|c|c|c|}
\hline \multicolumn{7}{|c|}{ ANOVA $^{\mathrm{a}}$} \\
\hline Model & & Sum of Squares & df & Mean Square & $\mathbf{F}$ & Sig. \\
\hline \multirow{3}{*}{1} & Regression & 2803,714 & 1 & 2803,714 & 732,963 &, $000^{\mathrm{b}}$ \\
\hline & Residual & 566,126 & 148 & 3,825 & & \\
\hline & Total & 3369,840 & 149 & & & \\
\hline
\end{tabular}

a. Dependent Variable: $Y$.

b. Predictors: (Constant), $\mathrm{X}^{1}$.

The results of the analysis in Table 7 show that Significant $F=0,000<\alpha=0.05$. This means that $X^{1}$ has an effect on Y. To determine the magnitude of the effect of $\mathrm{X}^{1}$ on $\mathrm{Y}$, the following results are shown in a simple regression analysis (Model Summary) in Table 8.

Table 8. Summary $X^{l}$ model against $Y$.

\begin{tabular}{lllll}
\hline Model Summary & & & \\
\hline Model & R & R Square & Adjusted R Square & Std. Error of the Estimate \\
\hline 1 &, $912^{\mathrm{a}}$ &, 832 &, 831 & 1,95581 \\
\hline
\end{tabular}

a. Predictors: (Constant), $\mathrm{X}^{1}$.

The results of the analysis in Table 8 show that $\mathrm{R}$ Square $=0.832$. This figure shows that the magnitude of the effect of $\mathrm{X}^{1}$ on $\mathrm{Y}=83.20 \%$. There are other variables of $16.80 \%$ which are not included in the analysis model. To find out whether X1 contributes to $\mathrm{Y}$, the following are the results of a simple regression analysis (Coefficients) in Table 9.

Table 9. $X^{l}$ contribution to $Y$.

\begin{tabular}{|c|c|c|c|c|c|c|}
\hline \multicolumn{7}{|c|}{ Coefficients $^{\mathrm{a}}$} \\
\hline \multirow{2}{*}{\multicolumn{2}{|c|}{ Model }} & \multicolumn{2}{|c|}{ Unstandardized Coefficients } & \multirow{2}{*}{$\begin{array}{l}\text { Standardized Coefficients } \\
\text { Beta }\end{array}$} & \multirow[b]{2}{*}{ t } & \multirow{2}{*}{ Sig. } \\
\hline & & B & Std. Error & & & \\
\hline & (Constant) & 7,780 & ,660 & & 11,786 & 000 \\
\hline & $\mathrm{X}^{1}$ & 3,010 &, 111 & ,912 & 27,073 &, 000 \\
\hline
\end{tabular}

a. Dependent Variable: Y.

The results of the analysis in Table 9 look significant $t=0,000<\alpha=0.05$. This means that $\mathrm{X}^{1}$ contributes to $\mathrm{Y}$. $\mathrm{B}=3.010$, this number shows that the amount of contribution $\mathrm{X}^{1}$ to $\mathrm{Y}=3.010$. Thus when $\mathrm{X}^{1}$ is increased by one part, $\mathrm{Y}$ increases by 3.010 .

\subsection{Effect of $X^{2}$ on $Y$}

To find out the effect of $\mathrm{X}^{2}$ on $\mathrm{Y}$, the following are the results of a simple regression analysis (Anova Table) in Table 10.

Table 10. Effect of $X^{2}$ on $Y$.

\begin{tabular}{lllllll}
\hline ANOVA $^{\text {a }}$ & & & & & \\
\hline Model & & Sum of Squares & df & Mean Square & F & Sig. \\
\hline \multirow{3}{*}{1} & Regression & 2723,297 & 1 & 2723,297 & 623,390 &, $000^{\mathrm{b}}$ \\
& Residual & 646,543 & 148 & 4,369 & & \\
& Total & 3369,840 & 149 & & & \\
\hline
\end{tabular}

a. Dependent Variable: Y.

b. Predictors: (Constant), $X^{2}$.

The results of the analysis in Table 10 show that Significant $F=0,000<\alpha=0.05$. This means that $\mathrm{X}^{2}$ has an effect on $\mathrm{Y}$. To find out the magnitude of the effect of $\mathrm{X}^{2}$ on $\mathrm{Y}$, the following are the results of a simple regression analysis (Model Summary) in Table 11.

Table 11. Summary $X^{2}$ model against $Y$.

\begin{tabular}{lllll}
\hline Model Summary & & & \\
\hline Model & R & R Square & Adjusted R Square & Std. Error of the Estimate \\
\hline 1 &, $899^{\mathrm{a}}$ &, 808 &, 807 & 2,09010 \\
\hline
\end{tabular}

a. Predictors: (Constant), $\mathrm{X}^{2}$ 
The results of the analysis in Table 11 show that $\mathrm{R}$ Square $=0.808$. This figure shows that the magnitude of the effect of $\mathrm{X}^{2}$ on $\mathrm{Y}=80.80 \%$. There are other variables of $19.20 \%$ which are not included in the analysis model. To find out whether $\mathrm{X}^{2}$ contributes to $\mathrm{Y}$, the following are the results of a simple regression analysis (Coefficients) in Table 12.

Table 12. Contribution of $X^{2}$ to $Y$.

\begin{tabular}{|c|c|c|c|c|c|}
\hline Coefficients $^{\mathrm{a}}$ & & & & & \\
\hline \multirow{2}{*}{ Model } & \multicolumn{2}{|c|}{ Unstandardized Coefficients } & \multirow{2}{*}{$\begin{array}{l}\text { Standardized Coefficients } \\
\text { Beta }\end{array}$} & \multirow{2}{*}{$\mathbf{t}$} & \multirow{2}{*}{ Sig. } \\
\hline & B & Std. Error & & & \\
\hline (Constant) & 8,449 & ,689 & & 12,261 &, 000 \\
\hline $\mathrm{X}^{2}$ & 2,904 & ,116 & 899 & 24,968 &, 000 \\
\hline
\end{tabular}

a. Dependent Variable: Y.

The results of the analysis in Table 12 . Seen Significantly $t=0,000<\alpha=0.05$. This means that $X^{2}$ contributes to $Y$. $B=$ 2.904, this number shows that the contribution of $\mathrm{X}^{2}$ to $\mathrm{Y}=2.904$. Thus, when $\mathrm{X}^{2}$ is increased by one part, $\mathrm{Y}$ increases by 2.904 .

\subsection{Effect of $X^{3}$ on $Y$}

To find out the effect of $\mathrm{X}^{3}$ on $\mathrm{Y}$, the following are the results of a simple regression analysis (Anova Table) in Table 13.

Table 13. Effect of $X^{3}$ on $Y$.

\begin{tabular}{llllll}
\hline ANOVA $^{\mathbf{a}}$ & & & & \\
\hline Model & Sum of Squares & df & Mean Square & F & Sig. \\
\hline \multicolumn{1}{c}{ Regression } & 2715,764 & 1 & 2715,764 & 614,505 &, $000^{\mathrm{b}}$ \\
$1 \quad$ Residual & 654,076 & 148 & 4,419 & & \\
\multicolumn{1}{l}{ Total } & 3369,840 & 149 & & & \\
\hline
\end{tabular}

a. Dependent Variable: Y.

b. Predictors: (Constant), $\mathrm{X}^{3}$.

The results of the analysis in Table 13 show that Significant $F=0,000<\alpha=0.05$. This means that $\mathrm{X}^{3}$ has an effect on $\mathrm{Y}$. To find out the magnitude of the effect of $\mathrm{X}^{3}$ on $\mathrm{Y}$, the following are the results of a simple regression analysis (Model Summary) in Table 14.

Table 14. Summary $X^{3}$ model against $Y$.

\begin{tabular}{lllll}
\hline Model Summary & & & \\
\hline Model & R & R Square & Adjusted R Square & Std. Error of the Estimate \\
\hline 1 &, $898^{\mathrm{a}}$ &, 806 &, 805 & 2,10224 \\
\hline
\end{tabular}

a. Predictors: (Constant), $\mathrm{X}^{3}$.

The results of the analysis in Table 14 show that $\mathrm{R}$ Square $=0.806$. This figure shows that the magnitude of the effect of $\mathrm{X}^{3}$ on $\mathrm{Y}=80.60 \%$. There is another variable of $19.40 \%$ which was not included in the analysis model. To find out whether $\mathrm{X}^{3}$ contributes to $\mathrm{Y}$, the following are the results of a simple regression analysis (Coefficients) in Table 15.

Table 15. $X^{3}$ contribution to $Y$.

\begin{tabular}{|c|c|c|c|c|c|c|}
\hline \multicolumn{7}{|c|}{ Coefficients $^{\mathrm{a}}$} \\
\hline \multirow{2}{*}{\multicolumn{2}{|c|}{ Model }} & \multicolumn{2}{|c|}{ Unstandardized Coefficients } & \multirow{2}{*}{$\begin{array}{l}\text { Standardized Coefficients } \\
\text { Beta }\end{array}$} & \multirow{2}{*}{$\mathbf{t}$} & \multirow{2}{*}{ Sig. } \\
\hline & & B & Std. Error & & & \\
\hline \multirow{2}{*}{1} & (Constant) & $-1,037$ & 1,069 & &,- 970 & ,334 \\
\hline & $\mathrm{X}^{3}$ &, 838 & 034 & ,898 & 24,789 &, 000 \\
\hline
\end{tabular}

a. Dependent Variable: Y.

The results of the analysis in Table 15 . Seen Significantly $t=0,000<\alpha=0.05$. This means $\mathrm{X}^{3}$ contributes to $\mathrm{Y}$. $\mathrm{B}=0.838$, this figure shows that the amount of contribution $\mathrm{X}^{3}$ to $\mathrm{Y}=0.838$. Thus, if $\mathrm{X}^{3}$ is increased by one part, $\mathrm{Y}$ increases by 0.838 .

\subsection{Effect of $X^{4}$ against $Y$}

To find out the effect of $\mathrm{X}^{4}$ on $\mathrm{Y}$, the following are the results of a simple regression analysis (Anova Table) in Table 16. 
Table 16. Effect of $X^{4}$ on $Y$.

\begin{tabular}{|c|c|c|c|c|c|c|}
\hline \multicolumn{7}{|c|}{ ANOVA $^{a}$} \\
\hline & & Sum of Squares & df & Mean Square & $\mathbf{F}$ & Sig. \\
\hline \multirow{3}{*}{1} & Regression & 2523,398 & 1 & 2523,398 & 441,215 &, $000^{\mathrm{b}}$ \\
\hline & Residual & 846,442 & 148 & 5,719 & & \\
\hline & Total & 3369,840 & 149 & & & \\
\hline
\end{tabular}

a. Dependent Variable: Y.

b. Predictors: (Constant), $\mathrm{X}^{4}$.

The results of the analysis in Table 16 show that Significant $F=0,000<\alpha=0.05$. This means that $\mathrm{X}^{4}$ has an effect on $\mathrm{Y}$. To find out the magnitude of the effect of $\mathrm{X}^{4}$ on $\mathrm{Y}$, the following are the results of a simple regression analysis (Model Summary) in Table 17.

Table 17. Summary $X^{4}$ model against $Y$.

\begin{tabular}{lllll}
\hline Model Summary & & & & \\
\hline Model & R & R Square & Adjusted R Square & Std. Error of the Estimate \\
\hline 1 &, $865^{\text {a }}$ &, 749 &, 747 & 2,39149 \\
\hline
\end{tabular}

a. Predictors: (Constant), $\mathrm{X}^{4}$.

The results of the analysis in Table 17 show that $\mathrm{R}$ Square $=0.865$. This figure shows that the magnitude of the effect of $\mathrm{X}^{4}$ on $\mathrm{Y}=86.50 \%$. There are other variables of $13.50 \%$ which are not included in the analysis model. To find out whether $\mathrm{X}^{4}$ contributes to $\mathrm{Y}$, the following are the results of a simple regression analysis (Coefficients) in Table 18.

Table 18. $X^{4}$ contribution to $Y$.

\begin{tabular}{|c|c|c|c|c|c|c|}
\hline \multicolumn{7}{|c|}{ Coefficients $^{\mathrm{a}}$} \\
\hline \multirow{2}{*}{ Model } & & \multicolumn{2}{|c|}{ Unstandardized Coefficients } & \multirow{2}{*}{$\begin{array}{l}\text { Standardized Coefficients } \\
\text { Beta }\end{array}$} & \multirow{2}{*}{$\mathbf{t}$} & \multirow{2}{*}{ Sig. } \\
\hline & & B & Std. Error & & & \\
\hline & (Constant) & ,058 & 1,209 & & ,048 & ,962 \\
\hline & $X^{4}$ &, 795 &, 038 & ,865 & 21,005 &, 000 \\
\hline
\end{tabular}

a. Dependent Variable: Y.

The results of the analysis in Table 18 . Seen Significantly $t=0,000<\alpha=0.05$. This means that $\mathrm{X}^{4}$ contributes to $\mathrm{Y}$. $\mathrm{B}=$ 0.795 , this figure shows that the amount of contribution $X^{4}$ to $Y=0.795$. Thus, if $X^{4}$ is increased by one part, $Y$ increases by 0.795 .

\subsection{Joint Effects of $X^{1}, X^{2}, X^{3}$, and $X^{4}$ on $Y$}

To find out the effect of $\mathrm{X}^{1}, \mathrm{X}^{2}, \mathrm{X}^{3}, \mathrm{X}^{4}$ together on $\mathrm{Y}$, the following are the results of multiple regression analysis (Anova Table) in Table 19.

Table 19. Effects of $X^{1}, X^{2}, X^{3}, X^{4}$ together on $Y$.

\begin{tabular}{lllllll}
\hline ANOVA $^{\mathbf{a}}$ & & & & & \\
\hline Model & & Sum of Squares & df & Mean Square & F & Sig. \\
\hline \multirow{2}{*}{1} & Regression & 3120,652 & 4 & 780,163 & 453,970 &, $000^{\mathrm{b}}$ \\
& Residual & 249,188 & 145 & 1,719 & & \\
& Total & 3369,840 & 149 & & & \\
\hline
\end{tabular}

a. Dependent Variable: $\mathrm{Y}$.

b. Predictors: (Constant), $\mathrm{X}^{1}, \mathrm{X}^{2}, \mathrm{X}^{3}, \mathrm{X}^{4}$.

From Table 19 it can be seen that Significant $F=0,000<\alpha=0.05$. This means that $X^{1}, X^{2}, X^{3}, X^{4}$ together have an effect on $\mathrm{Y}$. To find out the effect of $\mathrm{X}^{1}, \mathrm{X}^{2}, \mathrm{X}^{3}, \mathrm{X}^{4}$ together influence $\mathrm{Y}$, the following are the results of multiple regression analysis (model summary) in Table 20.

Table 20. The magnitude of the effect of $X^{1}, X^{2}, X^{3}, X^{4}$ together influences $Y$.

\begin{tabular}{lllll}
\hline Model Summary & & & \\
\hline Model & R & R Square & Adjusted R Square & Std. Error of the Estimate \\
\hline 1 &, $962^{\mathrm{a}}$ &, 926 &, 924 & 1,31093 \\
\hline
\end{tabular}

a. Predictors: (Constant), $\mathrm{X}^{1}, \mathrm{X}^{2}, \mathrm{X}^{3}, \mathrm{X}^{4}$. 
Based on Table 20 it can be seen that the coefficient of determination (R Square) $=0.926$. This figure shows that the magnitude of the influence of $\mathrm{X}^{1}, \mathrm{X}^{2}, \mathrm{X}^{3}, \mathrm{X}^{4}$ together has an effect on $\mathrm{Y}$ is $92.60 \%$. To find out whether $\mathrm{X}^{1}, \mathrm{X}^{2}, \mathrm{X}^{3}, \mathrm{X}^{4}$ contribute significantly to $\mathrm{Y}$, the following are the results of multiple regression analysis (coefficients) in Table 21 .

Table 21. Contributions of $X^{1}, X^{2}, X^{3}, X^{4}$ to $Y$.

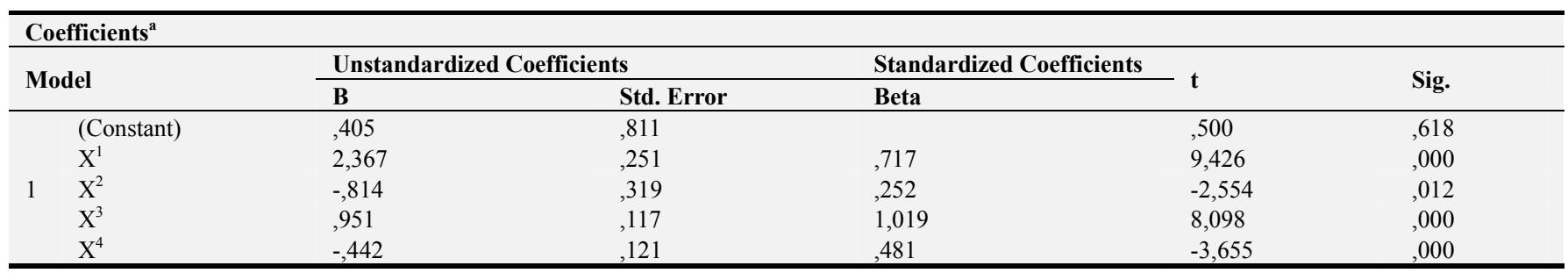

The results of regression analysis conducted on $\mathrm{X}^{1}, \mathrm{X}^{2}, \mathrm{X}^{3}$, and $\mathrm{X}^{4}$ double $\mathrm{X}^{1}, \mathrm{X}^{2}, \mathrm{X}^{3}$, and $\mathrm{X}^{4}$ on $\mathrm{Y}$ using ANOVA Table showed that it has a significant value of $F=0,000$ which is smaller than Alpha $=0.05$. This shows that $X^{1}, X^{2}, X^{3}$, and $\mathrm{X}^{4}$ have a joint effect on $\mathrm{Y}$. The coefficient of determination (R Square) was found to be 0.962 and this means that the magnitude of the joint influence of $\mathrm{X}^{1}, \mathrm{X}^{2}, \mathrm{X}^{3}$, and $\mathrm{X}^{4}$ on $\mathrm{Y}$ is $96.20 \%$. The joint contribution of $X^{1}, X^{2}, X^{3}$, and $X^{4}$ is equal to $=7.547$. In other words, if $X^{1}, X^{2}, X^{3}$, and $X^{4}$ are increased by one part, $\mathrm{Y}$ will increase by 7.547 .

\section{Discussion}

Based on the results of this study, it was found that the behavior of the community to provide drainage around their homes was in the moderate category. The results of this study, together with the results of a study conducted by Mithen, to determine the behavior of the community in maintaining a residential environment in the Mamasa river basin, which is in the medium category [19]. Likewise, the results of the Hafid study, which examined the behavior of people in the city of Makassar to maintain the environment, especially green open spaces and the results were in the medium category [20]. Of the three research results in three different regions on Sulawesi Island, the results were the same.

Therefore, from the analysis above, it can be discovered that there is a need for improvement of the behavior of inhabitants of stage houses in Soppeng Regency. This can be initiated by increasing their knowledge on the conservation of the environment through training and counseling.

They must also be motivated to maintain the environment and change their attitudes towards it through the provision of a model of a healthy environment as well as in helping them to apply the knowledge in their community.

\section{Conclusion}

It can be concluded that the behavior of inhabitants of Soppeng Regency towards the environment is moderate and calls for improvement. It can also be concluded that environment factors such as environmental knowledge, environmental conservation knowledge, attitudes towards the environment and motivation to maintain the environment are moderate and individually and jointly influence the behavior of the inhabitants. Therefore, they must also be improved.

\section{References}

[1] Undang-Undang Republik Indonesia Nomor 32 Tahun (2009) Tentang Perlindungan dan Pengelolaan Lingkungan Hidup.

[2] Salim, Emil, (1986). Pembangunan Berwawasan Lingkungan, LP3ES, Jakarta.

[3] Hungerford, Horald D. and Volk, Trudi L. (1990). "Changing Leaner Behavior Through Environmental Education". Journal of Environmental Education. 21 (3) Spring. pp. 8-21. Illinois USA.

[4] Tukiyat., (2009). Perilaku Masyarakat Situ Rawa Besar dalam Mengelola Lingkungan. Sinopsis Disertasi. Jakarta: Program Pascasarjana Universitas Negeri Jakarta.

[5] Adnil, Edwin Nurdin (2011). Tumbuh Kembang Perilaku Manusia. Jakarta: Penerbit Buku Kedokteran EGC.

[6] Rambo, (1981). Conceptual Approaches To Human Ecology. A Source Book on Alternative Pardigma for the Study of Human Interaction with the Environment. Sourcebook has been prepared for distribution to participants in The EAPI workshop on Human Ecology Research for Social Scientist.

[7] Sarwono, S. W. (2007). Psikologi Lingkungan. Jakarta: PT. Gramedia.

[8] Notoatmodjo, S. (2003). Pendidikan Dan Perilaku Kesehatan. Jakarta: Rineka Cipta.

[9] Rakhmat, Jalaluddin, (2011). Psikologi Komunikasi. Bandung: PT. Remaja Rosdakarya.

[10] Achmadi, (2012). Psikologi Sosial. Jakarta: Rineka Cipta.

[11] Adnani H., 2011. Ilmu Kesehatan Masyarakat, Cetakan 1, Penerbit Nuha Medika, Yoyakarta.

[12] Frytxell, Gerald E. \& Lo, Carlos W. H. (2003). The Influence of Environmental Knowledge and Values on Managerial Behaviours on Behalf of the Environment: An Empirical Examination of Managers in China. Journal of Business Ethics 46 (1): 45-69.

[13] Tisdale, S., W. L Nelson and J. D. Beaon, (1990\}. Soil Fertility and Fertilizers. 4th edition. Macmillan Publishing Company. New York. 
[14] Azwar, S, (2012). Sikap Manusia, Teori dan Pengukurannya. Yogyakarta: Pustaka Pelajar.

[15] Linggasari,. (2008). Faktor-faktor yang mempengaruhi Perilaku. (lontar.ui.ac.id/ file?file=digital/ 122941-S-5402Faktor...Literatur.pdf. diakses 28 Maret 2014).

[16] Ojedokun, O. (2011). "Attitude towards littering as a mediator of the relationship between personality attributes and responsible environmental behavior" Waste management journal 31 (12), 2601-2611.

[17] Soewarno, S. (2007). Sosiologi Kesehatan (Beberapa Konsep dan Aplikasinya). Cetakan keempat, Penerbit Gadjah Mada University Press, Yogyakarta.
[18] Djamarah, Syaiful Bahri, and Taufik (2012). Psikologi Belajar. Guru dan Anak Didik Dalam Interaksi Edukatif Suatu Pendekatan Teoretis Psikologis. Jakarta: PT. Rineka Cipta.

[19] Mithen, (2014). Perilaku Masyarakat Memelihara Lingkungan Permukiman di Daerah Aliran Sungai (DAS) Mamasa. Makassar: Disertasi PPS-UNM.

[20] Hafif, Sarfa. 2018. Analisis Pengelolaan Ruang Terbuka Hijau Pada Perumahan di Kota Makassar (Kajian Pengetahuan, Sikap, dan Perilaku Masyarakat). http://eprints.unm.ac.id/11566/1/Jurnal61.pdf. 